\title{
KINETIKA ADSORPSI ION EMAS(III) OLEH HIBRIDA MERKAPTO SILIKA
}

\author{
Saprini Hamdiani ${ }^{1}$, Nuryono², Bambang Rusdiarso² \\ ${ }^{1}$ Program Studi Kimia Fakultas Matematika dan Ilmu Pengetahuan Alam Universitas Mataram \\ ${ }^{2}$ Program Studi Kimia Fakultas Matematika dan Ilmu Pengetahuan Alam Universitas Gadjah Mada \\ E-mail : saprini_hamdiani@yahoo.com
}

\begin{abstract}
Abstrak: Telah dilakukan kajian kinetika adsorpsi ion emas(III) oleh adsorben hibrida merkapto silika (HMS). HMS disintesis melalui proses sol-gel dengan prekursor natrium silikat $\left(\mathrm{Na}_{2} \mathrm{SiO}_{3}\right)$ dari abu sekam padi. HMS dibuat dengan menambahkan asam klorida pada campuran senyawa 3-(trimetoksilil)-1-propantiol (TMSP) dan larutan $\mathrm{Na}_{2} \mathrm{SiO}_{3}$. Kinetika adsorpsi ditentukan dengan melakukan adsorpsi sistem statik (batch) dengan variasi waktu. Jumlah ion emas yang teradsorpsi dihitung secara kuantitatif berdasarkan selisih konsentrasi logam sebelum dan setelah adsorpsi yang dianalisis dengan spektroskopi serapan atom (SSA). Data menunjukkan interaksi HMS dengan ion emas cenderung mengikuti pola kinetika reaksi pseudo orde-2 dengan nilai konstanta laju reaksi $(\mathrm{k})=1 \times 10^{-2} \mathrm{~g} \mathrm{mg}^{-1} \mathrm{~min}^{-1}$. Berdasarkan nilai perubahan energi bebas Gibbs adsorpsi standar $\left(-\Delta \mathrm{G}^{\circ}=34,63-37,99 \mathrm{~kJ} / \mathrm{mol}\right)$ menunjukkan bahwa adsorpsi berlangsung secara kimia (kemisorpsi).
\end{abstract}

Kata kunci: kinetika, emas, merkapto, silika, abu sekam padi, pseudo orde-2.

Abstract: Adsorption kinetics study has been done of gold(III) ions by mercapto silica hybrid (MSH) adsorben. MSH was synthesized by sol-gel process with sodium silicate $\left(\mathrm{Na}_{2} \mathrm{SiO}_{3}\right)$ from rice husk ash as a precursor. MSH made by adding hydrochloric acid to 3-(trimetoksilil)-1-propantiol (TMSP) compounds and $\mathrm{Na}_{2} \mathrm{SiO}_{3}$ solution. Adsorption kinetics are determined by adsorption static system (batch) with variation of time. The amount of the adsorbed gold ions is quantified by the difference in metal concentration before and after adsorption analyzed by atomic absorption spectroscopy (AAS). The data showed, MSH interaction with gold ion tends to follow the pattern of reaction kinetics pseudo-second-order with rate constant $(\mathrm{k})=1 \times 10^{-2} \mathrm{~g} \mathrm{mg}^{-1} \mathrm{~min}^{-1}$. Based on the value of the standard Gibbs free energy for adsorption $\left(-\Delta \mathrm{G}^{\circ}=34,63-37,99 \mathrm{~kJ} / \mathrm{mol}\right)$ showed that the adsorption takes place chemically (chemisorption).

Keywords: kinetics, gold, mercapto, silica, rice husk ash, pseudo-second-order.

\section{PENDAHUluan}

Sekam padi memiliki kandungan $\mathrm{SiO}_{2}$ sebanyak $89,47-98 \%$ [1]. Kandungan ini diperoleh setelah sekam padi melalui proses pembakaran menjadi abu [2]. Silika gel yang dihasilkan dari abu sekam padi memiliki gugus fungsi silanol $(-\mathrm{Si}-\mathrm{OH})$ dan siloksan $(\mathrm{Si}-\mathrm{O}-\mathrm{Si})$ sehingga mampu mengadsorpsi ion logam keras. Agar dapat mengadsorpsi ion logam lunak seperti emas, maka silika gel dimodifikasi dengan penambahan reagen 3trimetoksilil-1-propantiol (TMSP). TMSP memiliki gugus fungsional thiol (-SH) yang bersifat lunak [3]. TMSP berfungsi sebagai reagen organik untuk modifikasi permukaan silika gel menghasilkan suatu adsorben hibrida organik-anorganik (hibrida merkapto-silika) yang diharapkan memiliki kemampuan adsorpsi yang baik terhadap emas.

Kajian kinetika adsorpsi HMS terhadap logam $\mathrm{Au}(\mathrm{III})$ dikaji dengan menggunakan model kinetika reaksi orde-1, orde-2, pseudo orde-1 dan pseudo-orde-2. Kinetika adsorpsi dipelajari dengan menghitung konsentrasi sisa $\mathrm{Au}(\mathrm{III})$ setelah adsorpsi dalam berbagai variasi waktu adsorpsi. Model kinetika reaksi orde 1 (pers.1) dan orde-2 (pers.2) menurut Moore dan Pearson (1981) [4] adalah sebagai berikut:

$$
\begin{aligned}
& \ln C e=-k 1 \mathrm{t}+\ln \mathrm{C} \ldots \ldots .(1) \\
& (1 / C e)=k 2 \mathrm{t}+(1 / C o) \ldots .(2)
\end{aligned}
$$

Kinetika reaksi pseudo orde-1 (pers.3) dan pseudo reaksi orde-2 (pers.4) ditentukan dengan persamaan Lagergren (1898) [5], sebagai berikut:

$\log (q e-q t)=\log q e-\left(k_{3} / 2,303\right) t \ldots(3)$

$t / q t=1 /(k 4 q e 2)+(1 / q e) t$.

dimana, $\mathrm{C}_{\mathrm{e}}$ adalah konsentrasi sisa $\mathrm{Au}(\mathrm{III})$ pada saat waktu $=\mathrm{t}\left(\mathrm{mmolL}^{-1}\right) \mathrm{C}_{\mathrm{o}}$ adalah konsentrasi awal Au(III) $\left(\mathrm{mmolL}^{-1}\right)$, qe dan $\mathrm{q}_{\mathrm{t}}$ adalah jumlah $\mathrm{Au}(\mathrm{III})$ teradsorpsi setelah setimbang dan pada saat $\mathrm{t}, k_{1}$ dan $k_{2}$ adalah masing-masing konstanta laju reaksi orde-1 dan orde- $2, k_{3}$ dan $k_{4}$ adalah masing-masing laju reaksi pseudo orde 1 dan pseudo orde-2.

\section{METODE PENELITIAN}

\section{Pengolahan abu sekam padi menjadi larutan natrium silikat.}

Sampel serbuk abu sekam padi ditambahkan dengan $200 \mathrm{~mL} \mathrm{NaOH}$ 4M (Alba Chemical), kemudian dididihkan. Setelah mengental, larutan dituangkan ke dalam cawan porselin dan dilebur pada temperatur $500{ }^{\circ} \mathrm{C}$ selama 30 menit. Setelah dingin ditambahkan akuades (Lab.Kimia Analitik UGM), dibiarkan semalam dan disaring. Filtrat yang dihasilkan merupakan larutan natrium silikat $\left(\mathrm{Na} 2 \mathrm{SiO}_{4}\right)$. 
Hibridisasi senyawa merkapto pada silika melalui proses sol-gel.

Larutan natrium silikat, ditambahkan senyawa 3(trimetoksisilil)-1propantiol (TMSP) (Merck). Selanjutnya ditambahkan $\mathrm{HCl}$ 3M (Alba Chemical) secara bertetes-tetes hingga terbentuk gel. Gel dikeringkan.

Kajian kinetika adsorpsi emas oleh adsorben hibrida merkapto silika

Sebanyak 10 mg HMS ditambah larutan $\mathrm{HAuCl}_{4}$ (Lab.Kimia Analitik UGM) 100 ppm. Kontak antara adsorben dengan larutan logam dilakukan pada variasi waktu 2, 4, 6, 8, 10, 15, 20,25 dan 30 menit dengan $\mathrm{pH}$ konstan. Campuran adsorben dan larutan logam diaduk dengan pengaduk magnet. Selanjutnya larutan disentrifuse dengan kecepatan 2000 rpm untuk memisahkan supernatan dan adsorben. Supernatan dianalisis dengan spektrofotometer serapan atom (SSA).

\section{Energi adsorpsi}

Adsorpsi dilakukan dalam sistem batch dengan membuat variasi konsentrasi larutan $\mathrm{HAuCl} 4$ dengan konsentrasi: $25,50,100,150,200,300 \mathrm{mg} / \mathrm{L}$ pada $\mathrm{pH}=3$ dan waktu kontak 25 menit. Termodinamika adsorpsi dikaji berdasarkan persamaan isotherm adsorpsi Langmuir dan Freundlich.

\section{HASIL DAN PEMBAHASAN}

Karakterisasi adsorben hibrida merkapto-silika (HMS) dilakukan dengan metode spektroskopi inframerah (FTIR) untuk identifikasi gugus fungsional dan difraksi sinar-X (XRD) mengetahui kekristalan HMS. Berikut adalah data FTIR dari HMS

Tabel 1: Data IR HMS (Hamdiani, S. dkk., 2010) [6].

\begin{tabular}{lcl}
\hline No & $\begin{array}{c}\text { Bilangan } \\
\text { gelomban } \\
\mathrm{g}\left(\mathrm{cm}^{-1}\right)\end{array}$ & \multicolumn{1}{c}{ Gugus fungsional } \\
\hline 1 & 3425,6 & $\begin{array}{l}\text { Gugus hidroksi (-OH) pada gugus } \\
\text { silanol (Si-OH) }\end{array}$ \\
2 & 2931,6 & Vibrasi gugus -CH \\
3 & 2553,8 & Gugus -SH \\
4 & 1627,9 & $\begin{array}{l}\text { Vibrasi tekuk gugus }-\mathrm{OH} \text { pada } \\
\text { silanol }\end{array}$ \\
5 & 1404,18 & $\begin{array}{l}\text { Vibrasi -C-C- dari metilen (- } \\
\text { CH2-) }\end{array}$ \\
6 & 1072,4 & $\begin{array}{l}\text { Vibrasi ulur asimetri gugus Si-O } \\
\text { dari siloksan (Si-O-Si) }\end{array}$ \\
7 & 918,1 & Vibrasi ulur Si-O pada Si-OH \\
8 & 462,9 & Vibrasi tekuk gugus Si-O-Si \\
\hline
\end{tabular}

Keberhasilan immobilisasi senyawa 3-(trimetoksilil)1propantiol melalui proses sol-gel ditunjukkan oleh munculnya pita serapan pada bilangan gelombang sekitar $2931,6 \mathrm{~cm}^{-1}$ yang merupakan serapan akibat vibrasi $-\mathrm{CH}$ dan juga pita serapan di daerah 1404,18 $\mathrm{cm}^{-1}$ yang merupakan serapan akibat vibrasi -C-C- dari gugus metilen $\left(-\mathrm{CH}_{2}-\right)$. Pita serapan untuk gugus $-\mathrm{SH}$ akan muncul pada bilangan gelombang $2600-2450 \mathrm{~cm}^{-1}$.

Kekristalan Hibrida Merkapto Silika. Informasi mengenai struktur padatan diberikan oleh difraktogram sinar-X melalui analisis pola difraksi sesuai dengan tingkat kristalinitasnya. Pola difraksi HMS menunjukkan pola yang melebar di sekitar $2 \theta=21-22{ }^{\circ} \mathrm{C}$. Silika dengan puncak melebar di sekitar $2 \theta=20-22{ }^{\circ} \mathrm{C}$ menunjukkan struktur amorf [7].

Adsorpsi emas pada adsorben hibrida merkapto silika Variasi waktu kontak antara adsorben dengan HMS dilakukan pada: 2, 4, 6, 8, 10, 15, 20, 25 dan 30 menit pada $\mathrm{pH}$ konstan, menghasilkan kurva seperti Gambar 1.

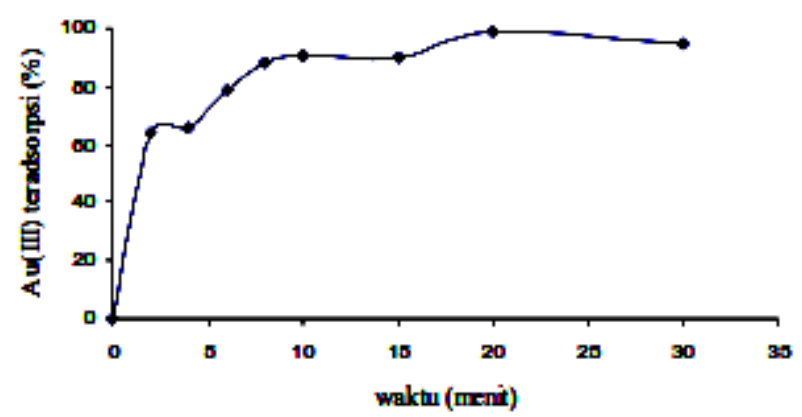

Gambar 1. Kurva waktu kontak adsorben HMS dengan ion logam emas

Adsorpsi emas oleh HMS mulai mencapai kesetimbangan saat adsorpsi berjalan 20-25 menit. Evaluasi kinetika adsorpsi HMS terhadap logam Au(III) dikaji dengan menggunakan model kinetika reaksi orde-1, orde-2, pseudo order-1 dan pseudo-orde-2 sesuai persamaan 1-4, menghasilkan kurva sebagai berikut:

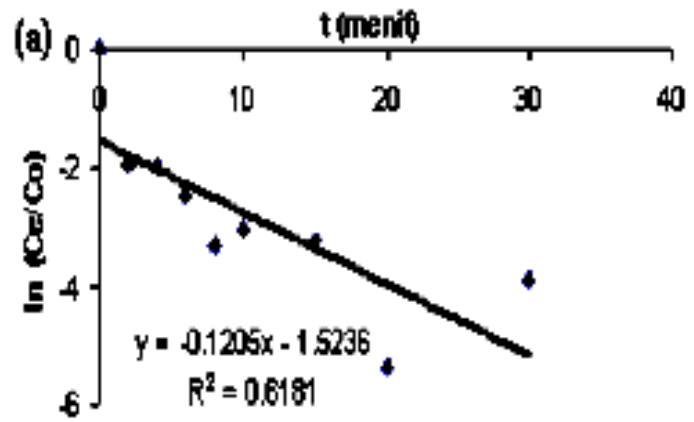

Gambar 2. Model kinetika reaksi orde 1

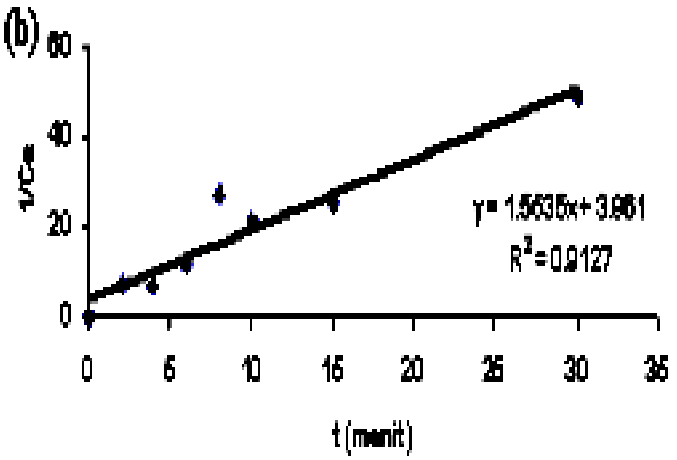

Gambar 3. Model kinetika reaksi orde 2 


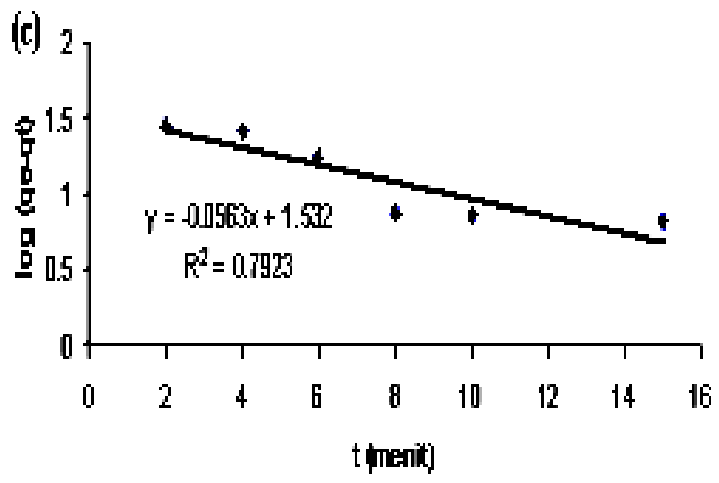

Gambar 4. Model kinetika reaksi pseudo orde-1

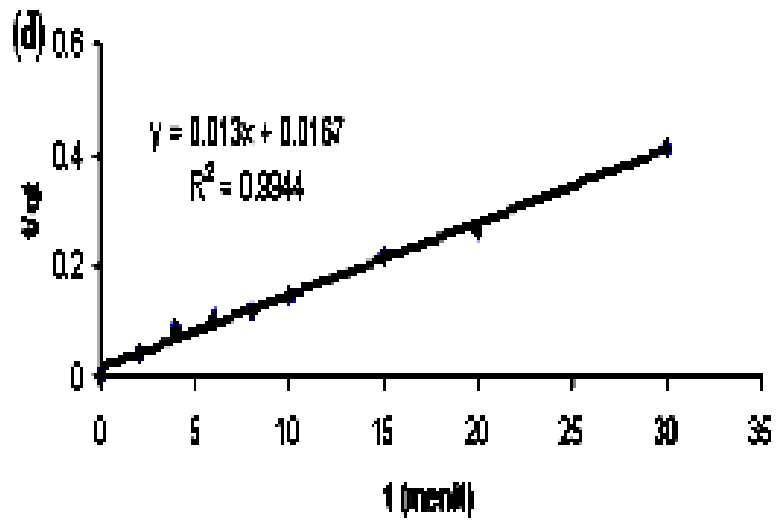

Gambar 5. Model kinetika reaksi pseudo orde-2

Tabel 2. Model kinetika adsorpsi HMS terhadap ion logam Au(III)

\begin{tabular}{lcc}
\hline \multicolumn{1}{c}{ Model kinetika } & Tetapan laju reaksi $(k)$ & $\mathrm{r}^{2}$ \\
\hline Orde-1 & $0,121 \mathrm{~min}^{-1}$ & 0,618 \\
Orde-2 & $1,553 \mathrm{M} \mathrm{min}^{-1}$ & 0,913 \\
Pseudo orde-1 & $0,024 \mathrm{~min}^{-1}$ & 0,792 \\
Pseudo orde-2 & $0,010 \mathrm{~g} \mathrm{mg}^{-1} \mathrm{~min}^{-1}$ & 0,994 \\
\hline
\end{tabular}

Menurut data kinetika dilihat dari linearitasnya, adsorpsi ion $\mathrm{Au}(\mathrm{III})$ oleh HMS cenderung mengikuti pola kinetika reaksi pseudo orde-2.

Model kinetika reaksi pseudo terjadi apabila terdapat reaktan dengan konsentrasi yang tidak berubah selama proses adsorpsi. Biasanya terjadi pada reaksi terkatalisis dengan konsentrasi katalis tetap sebelum maupun sesudah reaksi, pada reaksi dengan penggunaan buffer dimana konsentrasi ion $\mathrm{H}^{+}$tetap, dan reaksi-reaksi dimana konsentrasi salah satu reaktan sangat berlebih, sehingga persentase berkurangnya reaktan selama proses reaksi sangat kecil.

Kinetika reaksi adsorpsi HMS terhadap ion logam emas (III) berjalan sesuai dengan mekanisme reaksi pseudo orde-2. Hal ini dimungkinkan karena dalam proses reaksi digunakan buffer pada $\mathrm{pH}$ konstan $(\mathrm{pH}=3)$ sehingga konsentrasi $\mathrm{H}^{+}$yang ada dalam larutan tetap. Reaksi pseudo orde-2 pada adsorpsi Au(III) oleh HMS berdasarkan asumsi bahwa dengan berjalannya waktu konsentrasi $\mathrm{Au}(\mathrm{III})$ yang teradsorpsi akan semakin banyak dan mencapai titik jenuh setelah mencapai waktu 25 menit, ditandai dengan berkurangnya konsentrasi $\mathrm{Au}(\mathrm{III})$ yang teradsorpsi.

\section{Energi adsorpsi}

Energi adsorpsi mencerminkan seberapa kuat ikatan antar ion logam dengan situs aktif adsorben. Menurut Adamson (1997) [8], adsorpsi dimasukkan dalam kategori adsorpsi kimia (kemisorpsi) apabila nilai energi adsorpsi lebih dari 20,92 kJ/mol. Berdasarkan model isotherm adsorpsi Freundlich terlihat bahwa proses adsorpsi HMS berlangsung mengikuti proses adsorpsi kimia dengan energi adsorpsi berkisar antara 34,63-37,99 $\mathrm{kJ} / \mathrm{mol}$. Hal ini menunjukkan bahwa adsorbat terikat melalui pembentukan ikatan kimia pada permukaan hibrida merkapto silika.

\section{KESIMPULAN}

Kesetimbangan adsorpsi dicapai setelah adsorpsi berlangsung selama 25 menit. Model kinetika adsorpsi yang sesuai mengikuti kinetika reaksi pseudo orde-2 dengan nilai $\mathrm{k}=1 \times 10^{-2} \mathrm{~g} \mathrm{mg}^{-1} \mathrm{~min}^{-1}$ dan proses adsorpsi berlangsung secara kimia (kemisorpsi).

\section{DAFTAR PUSTAKA}

[1] Nuryono., Narsito., dan Astuti, E., 2004., Pengaruh Temperatur Pengabuan Sekam Padi Terhadap Karakter Abu dan Silika Gel Sintetik, Chem.Rev., 2 (7) 67-80.

[2] Chandrasekar, S., Pramada, P.N., Majeed, J., 2006., Effect of Calcination Temperature and Heating Rate on The Optical Properties and Reactivity of Rice Husk Ash., J. Mater.Sci., 41., 7926-7933.

[3] Huheey, E.J., Keiter. E.A., Keiter, R.L., 1993., Inorganic Chemistry Principle of Structure and Reactivity 4Th ed., Harper Collins College Publisher, New York.

[4] John W. Moore and Ralph G. Pearson., Kinetics and Mechnism, 3rd Edition, Wiley-Interscience, New York.

[5] Yuh-Shan Ho., 2004., Citation review of Lagergren kinetic rate equation on adsorption reactions., Scientometrics., Vol. 59., No. 1., 171-177.

[6] Hamdiani, S., Nuryono., Rusdiarso, B., 2010., Kajian Adsorpsi-Desorpsi Au(III) pada Hibrida Merkapto Silika., Prosiding Seminar Nasional., Universitas Negeri Yogyakarta.

[7] Kalapathy, U., Proctor, A., dan Shultz, J., 2000., A Simple Method for Production of Pure Silica from Rice Hull Ash., Bioresource Technology., 73., 257-262

[8] Adamson, A.W., dan Gast, A.P., 1997, Physical Chemistry of Surface, 6 edition, John Willey \& Sons, Inc., New York. 